\title{
Pengaruh Pertimbangan Pasar Kerja, Pelatihan Profesional, Dan Personalitas Terhadap Minat Mahasiswa Akuntansi Pada Pemilihan Karir
}

\author{
I Dewa Gde Ngurah Dananjaya ${ }^{1}$ \\ Fakultas Ekonomi dan Bisnis \\ Universitas Udayana, Indonesia. \\ Email: dodedananjaya54@gmail.com
}

\author{
Ni Ketut Rasmini2 \\ Fakultas Ekonomi dan Bisnis \\ Universitas Udayana, Indonesia.
}

\begin{abstract}
ABSTRAK
Karir merupakan bagian penting dalam kehidupan. Dalam memilih karir terdapat beberapa pertimbangan yaitu pertimbangan mengenai pasar kerja, pertimbangan mengenai pelatihan professional dan juga pengakuan personalitas. Ketiga pertimbangan ini menjadi dasar dalam pemilihan karir dimana memilih karir merupakan suatu keputusan besar yang berdampak pada masa depan. Mahasiswa akuntansi Fakultas Ekonomi dan Bisnis Universitas Udayana merupakan populasi penelitian ini. Dari 217 orang responden yang telah ditentukan melalui purposive sampling hanya 182 responden yang mengisi kuesioner. Analisis data pada penelitian ini menggunakan analisis regresi linear berganda. Hasil yang ditemukan adalah terdapat pengaruh positif antara variabel pertimbangan pasar kerja, pelatihan profesional serta personalitas terhadap minat mahasiswa akuntansi pada pemilihan karir.
\end{abstract}

Kata Kunci : $\quad$ Pertimbangan Pasar Kerja; Pelatihan Professional; Personalitas.

\section{Effects of Job Market Considerations, Professional Training, and Personality on Accounting Student Interest in Career Selection}

\begin{abstract}
Careers are an important part of life. In choosing a career there are a number of considerations, namely consideration of the labor market, consideration of professional training and also recognition of personality. These three considerations form the basis of career selection where choosing a career is a major decision that impacts the future. Accounting students at the Faculty of Economics and Business, Udayana University, are the study population. Of the 217 respondents who had been determined through purposive sampling, only 182 respondents filled out the questionnaire. Data analysis in this study uses multiple linear regression analysis. The results found are that there is a positive influence between the variables of labor market considerations, professional training and personality on accounting students' interests in career selection.
\end{abstract}

Keywords: Labor Market Considerations; Professional Training; Personality.

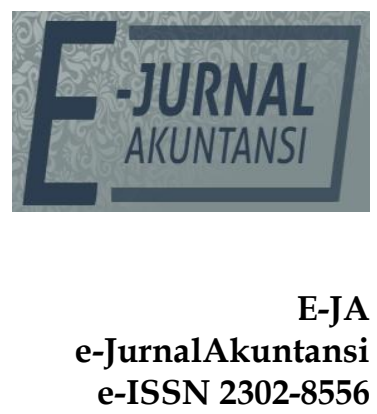

Vol. 29 No. 2

Denpasar, November

2019

Hal. 899-911

Artikel masuk:

28 Oktober 2019

Tanggal diterima: 22 November 2019 


\section{PENDAHULUAN}

Karir merupakan hal yang penting dalam kehidupan manusia.Setiap manusia memiliki pilihan karirnya masing-masing.Dalam memilih karir tersebut terdapat banyak pertimbangan.Seseorang cenderung memilih karir sesuai dengan minat serta bakat yang dimiliki. Karir yang dipilih tentunya diharapkan dapat memberikan masa depan yang menjanjikan.

Pendidikan merupakan faktor penting yang tidak dapat dipisahkan dari pemlihan karir. S1 banyak dipilih sebagai jenjang pendidikan untuk mewujudkan karir yang diimpikan.Pada penelitian ini meneliti lebih spesifik pada S1 akuntansi. Mahasiswa akuntansi memiliki beberapa pilihan ketika lulus dari S1. Pilihan pertama yaitu bekerja sesuai dengan latar belakang pendidikan yaitu S1, pilihan kedua yaitu melanjutkan ke tingkat pendidikan selanjutnya yaitu S2 dan satu lagi pilihan yang dimiliki oleh mahasiswa akuntansi yaitu melanjutkan pendidikan profesi akuntan.

Dalam memilih karir terdapat beberapa pertimbangan yaitu pertimbangan mengenai pasar kerja, pertimbangan mengenai pelatihan professional dan juga pengakuan personalitas. Ketiga pertimbangan ini menjadi dasar dalam pemilihan karir dimana memilih karir merupakan suatu keputusan besar yang berdampak pada masa depan.

Petimbangan pertama yaitu pertimbangan pasar kerja.Pertimbangan ini melihat seberapa luas pasar suatu pekerjaan.Pekerjaan dengan kesempatan atau peluang yang luas atau diminati banyak perusahaan tentu lebih memiliki banyak peminat jika dibandingkan dengan pekerjaan yang peluang atau kesempatannya lebih sempit.Perbedaan peluang ini dapat dijadikan pertimbangan dalam memilih suatu karir.Menurut Suroto (2016), pasar kerja yaitu semua permintaan serta penawaran dalam ketenaga kerjaan. Dimana masyarakat menawarkan tenaganya dan perusahaan memerlukan tenaga tersebut.

Pertimbangan selanjutnya yaitu pertimbangan professional.Untuk mahasiswa akuntansi, diberikann pilihan untuk melanjutkan pendidikan prosfesi akuntan dimana dalam pendidikan tersebut mahasiswa dapat melatih profesionalismenya pada bidang akuntan.Pendidikan profesi memberikan kesempatan mahasiswa untuk mendalami ilmu pada profesi yang ingin dijalaninya yang dalam penelitian ini adalah profesi akuntan. Selain pengembangan diri dan ilmu, motivasi mahasiswa dalam memilih pendidikan profesi juga dapat sebagai jalan untuk mendapatkan penghargaan finansial (Stolle, 1976).

Pertimbangan terakhir yaitu personalitas.Kecenderungan seseorang dalam berperilaku tertentu baik berpikir, berbicara maupun bertindak merupakan personalitas.Personalitas berdasarkan dari diri individu itu sendiri.Kecenderungan tersebut terbentuk dari lingkungan sekitarnya dan bukanlah sejak lahir. Pengalaman-pengalaman yang dialami oleh seorang individu membuatnya memiliki cara pandang yang berbeda dan unik untuk berperilaku. Oleh karena itu personalitas tiap individu memiliki keunikan masing-masing.

Penelitian ini diharapkan dapat memberikan manfaat bagi pihak-pihak yang berkepentingan, meliputi (1) Manfaat Teoretis. Hasil dari penelitian ini dapat memberikan sumbangan yang berarti dalam pengembangan ilmu 
akuntansi, khususnya pada bidang Theory Of Planned Behavior. Hasil dari penelitian ini juga dapat menjadi bahan referensi dan perbandingan untuk penelitian penelitian selanjutnya, (2) Manfaat Praktis. Manfaat praktis penelitian ini diharapkan dapat memberikan masukan dan tambahan referensi kepada mahasiswa akuntansi Universitas Udayana untuk mengembangkan serta mengoptimalkan kembali hasil penelitian ini.

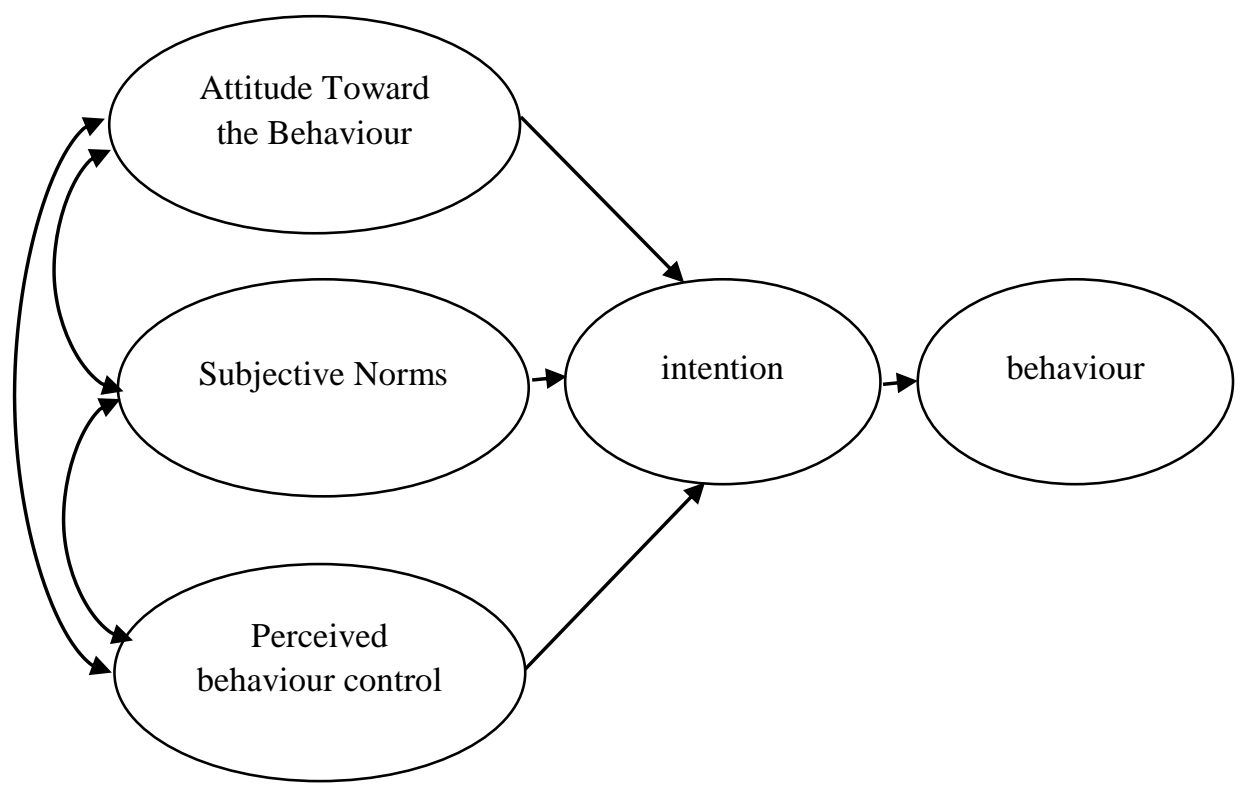

Gambar 1. Theory of Planned Behavior

Sumber: Ajzen \& Fishbein, 1998

Seseorang dalam berperilaku tentunya memiliki dasar atas apa yang dilakukannya. Theory of planned behaviormemberikan gambaran mengenai dasar seseorang dalam berperilaku. Niat merupakan salah satu dasar dari seseorang dalam berperilaku. Niat yang dimiliki oleh seseorang akan tercermin dari perilaku yang dilakukan karena niat atau intensi itulah alas an individu tersebut melakukan sesuatu. Selain niat terdapat juga norma substantif yang mendasari perilaku seseorang. Persepsi yang dimiliki seseorang dapat memengaruhi perilaku orang tersebut. Setiap individu memiliki persepsi atau cara pandang yang berbeda mengenai suatu hal. Perbedaan ini mendasari beragamnya perilaku orang-orang terhadap suatu situasi.Persepsi perilaku ini juga memberikan pertimbangan bagi individu untuk berperilaku tertentu atau tidak. Ketiga dasar yang telah disebutkan menjadi indikator pada penelitian ini (Ajzen \& Fishbein 1998).

Dasar seseorang dalam berperilaku yang telah dijelaskan dalam Theory of planned behaviorseperti yang sudah dijelaskan sebelumnya niat dapat menjadi dasar dalam berperilaku, dalam penelitian ini minat mahasiswa dalam menentukan karir dapat memberikan pilihan bagi mahasiswa akuntansi mengenai perilaku apa yang harus dilakukan. Beberapa hal yang dijadikan pertimbangan yaitu pasar kerja, pelatihan profesional dan personalitas.Ketiga hal ini dapat mengubah atau memantapkan minat dari mahasiswa akuntansi tergantung dari persepsi yang dimiliki oleh mahasiswa akuntansi tersebut. 
Pekerjaan dengan kesempatan atau peluang yang luas atau diminati banyak perusahaan tentu lebih memiliki banyak peminat jika dibandingkan dengan pekerjaan yang peluang atau kesempatannya lebih sempit.Perbedaan peluang ini dapat dijadikan pertimbangan dalam memilih suatu karir. Menurut Suroto (2016), pasar kerja yaitu semua permintaan serta penawaran dalam ketenaga kerjaan. Dimana masyarakat menawarkan tenaganya dan perusahaan memerlukan tenaga tersebut. Dalam mempertimbangkan pasar kerja, hal-hal yang biasa diperhatikan yaitu keamanan kerja, fleksibilitas karir dan kesempatan promosi (Harahap, 2017).

Pertimbangan pada pelatihan professional yaitu mahasiswa akuntansi melihat fasilitas pelatihan professional yang dapat diberikan oleh perusahaan ataupun pihak eksternal yang bekerja sama dengan perusahaan. Dalam memulai suatu pekerjaan pelatihan professional dapat menjadi bekal bagi mahasiswa akuntansi. Selain pada saat memulai pekerjaan, mahasiswa akuntansi juga dapat mempertimbangkan apakah perusahaan memberikan fasilitas pengembangan diri berupa pelatihan-pelatihan selama berada di perusahaan. Pelatihanpelatihan ini dapat mengembangkan kemampuan yang telah dimiliki dan dapat berpengaruh pada kinerja di kemudian hari (Nana, 2018).

Kecenderungan seseorang dalam berperilaku tertentu baik berpikir, berbicara maupun bertindak merupakan personalitas.Personalitas berdasarkan dari diri individu itu sendiri.Kecenderungan tersebut terbentuk dari lingkungan sekitarnya dan bukanlah sejak lahir. Pengalaman-pengalaman yang dialami oleh seorang individu membuatnya memiliki cara pandang yang berbeda dan unik untuk berperilaku. Oleh karena itu personalitas tiap individu memiliki keunikan masing-masing (Allport, 1961).

Perencanaan dalam berkarir merupakan strategi yang baik dalam mewujudkan karir yang diinginkan.Pada implementasinya, perlu adanya pengembangan karir yang dilakukan dalam upaya mencapai karir yang diinginkan.

Bekerja di KAP menjadi salah satu pilihan karir yang dipilah mahasiswa auntansi. Bekerja di suatu instansi tentunya memiliki kelebihan dan kekurangan.Bekerja di KAP dapat memperluas wawasan karena dapat mengetahui berbagai macam perusahaan.Terutama jika bekerja sebagai auditor di KAP, keuntungan yang didapatkan yaitu pengetahuan yang bervariasi mengenai perusahaan-perusahaan yang di audit, serta pengalaman-pengalaman audit yang telah dilakukan.Pengalaman dan pengetahuan yang dimiliki ini dapat menjadi incaran oleh perusahaan-perusahaaan nantinya. Namun kekurangan yang dialami sebagai auditor yaitu dengan jangka waktu yang singkat harus menyelesaikan banyak tugas sehingga cenderung lebih sering mengalami lembur (Rasmini, 2007).

Pekerjaan dengan kesempatan atau peluang yang luas atau diminati banyak perusahaan tentu lebih memiliki banyak peminat jika dibandingkan dengan pekerjaan yang peluang atau kesempatannya lebih sempit. Perbedaan peluang ini dapat dijadikan pertimbangan dalam memilih suatu karir. Menurut Suroto (2016), pasar kerja yaitu semua permintaan serta penawaran dalam ketenaga kerjaan. Dimana masyarakat menawarkan tenaganya dan perusahaan memerlukan tenaga tersebut. Dalam mempertimbangkan pasar kerja, hal-hal 
yang biasa diperhatikan yaitu keamanan kerja, fleksibilitas karir dan kesempatan promosi (Harahap, 2017). Suyono (2014) dan linanda (2016) pada penelitian sebelumnya menemukan adanya pengaruh positif antara hubungan pasar kerja pada minat pemilihan karir sebagai akuntan publik sehingga hipotesis pertama diusulkan.

$\mathrm{H}_{1}$ : Pertimbangan pasar kerja berpengaruh positif terhadap pemilihan karir. mahasiswa akuntansi sebagai akuntan publik.

Pertimbangan pada pelatihan professional yaitu mahasiswa akuntansi melihat fasilitas pelatihan professional yang dapat diberikan oleh perusahaan ataupun pihak eksternal yang bekerja sama dengan perusahaan. Dalam memulai suatu pekerjaan pelatihan professional dapat menjadi bekal bagi mahasiswa akuntansi. Selain pada saat memulai pekerjaan, mahasiswa akuntansi juga dapat mempertimbangkan apakah perusahaan memberikan fasilitas pengembangan diri berupa pelatihan-pelatihan selama berada di perusahaan. Pelatihanpelatihan ini dapat mengembangkan kemampuan yang telah dimiliki dan dapat berpengaruh pada kinerja di kemudian hari (Nana, 2018). Penelitian sebelumnya dilakukan oleh Ardianto (2014) dan Agmila (2015) pelatihan profesional berpengaruh terhadap pemilihan karir sehingga hipotesis kedua diusulkan.

$\mathrm{H}_{2}$ : Pelatihan profesional berpengaruh positif terhadap pemilihan karir mahasiswa akuntansi sebagai akuntan publik.

Kecenderungan seseorang dalam berperilaku tertentu baik berpikir, berbicara maupun bertindak merupakan personalitas.Personalitas berdasarkan dari diri individu itu sendiri.Kecenderungan tersebut terbentuk dari lingkungan sekitarnya dan bukanlah sejak lahir. Pengalaman-pengalaman yang dialami oleh seorang individu membuatnya memiliki cara pandang yang berbeda dan unik untuk berperilaku. Oleh karena itu personalitas tiap individu memiliki keunikan masing-masing.Dalam menentukan karir perlu disesuaikan dengan personalitas yang dimiliki.Karena keunikan personalitas tiap orang dapat menghasilkan hasil yang positif maupun negatif pada suatu karir.Melalui pelatihan profesional, efek negatif yang mungkin terjadi dapat dihindari. Karena pelatiahn memberikan pengalaman baru, pengetahuan dan persepsi mengenai pekerjaan yang akan dilakukan. (Suyono, 2014) dan (Ambari, 2017) dalam penelitian yang dilakukannya menemukan hubungan positif antara personalitas terhadap pemilihan karir sebagai akuntan publik

$\mathrm{H}_{3}$ : Personalitas berpengaruh positif terhadap pemilihan karir mahasiswa akuntansi sebagai akuntan publik.

\section{METODE PENELITIAN}

Lokasi dilakukannya penelitian yaitu Fakultas ekonomi dan Bisnis Universitas Udayana dengan minat mahasiswa akuntansi terhadap pemilihan karir sebagai objek penelitian.Pada penelitian ini digunakan skala Likert dengan lima pilihan jawaban untuk mengukur setiap variabel yang ada. Definisi operasional dari variabel-variabel tersebut dijabarkan sebagai berikut:

Pemilihan karir merupakan suatu rangkaian kegiatan kerja yang terpisahkan tetapi berkaitan, yang memberikan kesinambungan, ketentraman, dan arti dalam hidup seseorang (Gomes, 2000). Pertimbangan mahasiswa akuntansi untuk berkarir sesuai dengan latar belakang pendidikannya yaitu 
akuntansi dengan berkarir sebagai akuntan atau memilih berkarir diluar profesi akuntan menjadi tolak ukur minat mahasiswa akuntansi dalam memilih karir.Pemilihan karir mahasiswa akuntansi diukur dengan 4 indikator dengan 6 item pernyataan yang mengacu pada (Iswahudin, 2015).

Pertimbangan pasar kerja meliputi keamanan kerja dan tersedianya lapangan kerja atau kemudahan mengakses lapangan pekerjaan. Pertimbangan pasar kerja dapat diukur dengan 3 indikator dengan 3 item pernyataan yang mengacu pada Ambari (2017), yaitu pertama adalah keamanan dari karir yang dipilih, kedua akses informasi yang ditawarkan oleh lapangan pekerjaan atau mudahnya informasi mengenai lapangan pekerjaan tersebut, terakhir seberapa sulit dalam mendapatkan pekerjaan tersebut.

Latihan dimaksudkan untuk memperbaiki penguasaan berbagai ketrampilan dan teknik pelaksanaan kerja tertentu, terinci dan rutin. Pelatihan profesional dapat diukur dengan 3 indikator dengan 5 item pernyataan yang mengacu pada Efendi et al., (2007), yaitu Pelatihan sebelum kerja dan selama kerja, Pembelajaran berkelanjutan, Adanya pengakuan professional.

Personalitas merupakan salah satu hal yang penting terhadap perilaku individu saat berhadapan dengan situasi atau kondisi tertentu. Personalitas dapat diukur dengan 3 indikator dengan 6 item pernyataan yang mengacu pada Arif et al., (2018), yaitu: Kecepatan dan ketidaksabaran dalam mengerjakan sesuatu, Keterlibatan yang tinggi terhadap tugas, Dorongan kuat untuk bersaing.

Menggunakan teknik purposive samplingdalam menentukan sampel dimana menggunakan kriteria yaitu mahasiswa semester 6 pada tahun akademik 2016 yang masih aktif kuliah. Data mengenai besarnya populasi tersaji dalam Tabel 1.

Tabel 1. Jumlah Mahasiswa Prodi Akuntansi Angkatan 2016

\begin{tabular}{lll}
\hline No & Kelas & Jumlah \\
\hline 1 & Reguler Pagi & 169 \\
2 & Reguler Sore & 304 \\
& Total & 473 \\
\hline
\end{tabular}

Sumber: Fakultas Ekonomi Dan Bisnis Universitas Udayana, 2019

Penentuan jumlah sampel dalam penelitian ini menggunakan rumus Slovin dan didapatkan responden sebanyak 217 responden.

Digunakan dua metode pengumpulan data yaitu kuesioner dengan skala likert dan dokumentasi. Jenis data yang digunakan pada penelitian ini adalah data kuantitatif adalah data yang berupa angka atau data kualitatif yang diangkakan (Sugiyono, 2017). Sumber data yaitu data sekunder yaitu sumber yang tidak langsung memberikan data kepada pengumpul data, misalnya melalui orang lain dan dari dokumen (Sugiyono, 2017). Data sekunder dalam penelitian ini adalah jumlah mahasiswa prodi Akuntansi Universitas Udayana.

Analisis dengan uji F ini menurut Sugiyono (2017) digunakan untuk menguji antara satu variabel bebas secara bersamaan mempunyai hubungan yang nyata (significant) terhadap variabel terikat. Uji $\mathrm{F}$ digunakan untuk mengetahui apakah secara bersama-sama variabel bebas berpengaruh pada variable tetap. Pengujian hipotesis mempergunakan level of signifikan 5\%. Adapun kriteria penerimaan atau penolakan hipotesis yang diajukan adalah Ho ditolak jika F hitung $>\mathrm{F}$ tabel dan Ho diterima jika F hitung $\leq \mathrm{F}$ table. 


\section{HASIL DAN PEMBAHASAN}

Dilakukan penyebaran kuesioner melalui google form (online) untuk mengumpulkan data dari responden. Kegiatan ini dilakukan pada tanggal 10 Juni 2019 dengan jangka waktu 1 minggu dan berakhir pada tanggal 17 Juni 2019.Berikut pada Tabel 2.Terdapat rincian mengenai penyebaran kuesioner yang telah dilakukan.

\section{Tabel 2. Rincian Pengiriman dan Pengembalian Kuesioner}

\begin{tabular}{ll}
\hline \multicolumn{1}{c}{ Keterangan } & Jumlah \\
\hline Kuesioner yang disebar & 217 \\
Kuesioner yang tidak kembali & 35 \\
Kuesioner yang dikembalikan & 182 \\
Kuesioner yang digunakan & 182 \\
$\begin{array}{l}\text { Tingkat Pengembalian (Respons rate) } \\
\text { Kuesioner yang dikembalikan x 100\% }\end{array}$ & \\
$\begin{array}{l}\text { Kuesioner yang dikirim } \\
\text { Tingkat Pengembalian yang digunakan (useable response rate) }\end{array}$ & \\
$\begin{array}{l}\text { Kuesioner yang diolah x 100\% } \\
\text { Kuesioner yang dikirm }\end{array}$ & $100 \%$ \\
\hline
\end{tabular}

Sumber : Data Penelitian, 2019

Dari data yang diperoleh setelah melakukan penyebaran kuesioner, sebanyak 182 eksemplar kembali dari 217 eksemplar yang dibagikan. Persentase pengembalian kuesioner adalah sebesar $83,87 \%$.

Berikut pada Tabel 3.dijabarkan mengenai karakteristik mahasiswa akuntansi dimana merupakan responden pada penelitian ini.

Tabel 3. Karakteristik Mahasiswa Akuntansi

\begin{tabular}{|c|c|c|c|c|}
\hline No & Karakteristik & Klasifikasi & $\begin{array}{l}\text { Jumlah } \\
\text { Responden } \\
\text { (orang) }\end{array}$ & $\begin{array}{l}\text { Persentase } \\
\text { Responden } \\
(\%) \\
\end{array}$ \\
\hline \multirow{3}{*}{1} & \multirow{3}{*}{ Usia } & 19-20 Tahun & 42 & 23,08 \\
\hline & & 21-22 Tahun & 76 & 41,76 \\
\hline & & 23-24 Tahun & 64 & 35,16 \\
\hline \multicolumn{2}{|c|}{ Jumlah } & & 182 & 100 \\
\hline \multirow{2}{*}{2} & Jenis & Laki-laki & 85 & 46,70 \\
\hline & Kelamin & Perempuan & 97 & 53,30 \\
\hline \multirow{2}{*}{\multicolumn{2}{|c|}{ Jumlah }} & & 182 & 100 \\
\hline & & $2,50-2,99$ & 13 & 7,14 \\
\hline \multirow[t]{3}{*}{3} & IPK Mahasiswa & $3,00-3,49$ & 96 & 52,75 \\
\hline & & $3,50-4,00$ & 79 & 43,41 \\
\hline & Jumlah & & 182 & 100 \\
\hline
\end{tabular}

Sumber: Data Penelitian, 2019

Karakteristik dari responden yaitu mahasiswa akuntansi Fakultas Ekonomi dan Bisnis Universitas Udayana yang saat ini masih aktif dan berada pada semester keenam yaitu didominasi oleh mahasiswa perempuan yaitu sebanyak 97 orang sedangkan mahasiswa laki-laki sejumlah 85 orang. Untuk usia, dari 182 orang responden 76 orang berumur 21-22 tahun, sedangkan 64 orang berumur 23-24 tahun dan 42 orang berumur 19-20 tahun. Untuk IPK yang dimiliki oleh responden mayoritas memiliki IPK pada range 3,00 hingga 3,49 dilihat dari 
persentasi yaitu lebih dari 50 persen tepatnya 52,75 persen responden memiliki IPK pada range tersebut. 79 orang memiliki IPK 3,50 hingga 4,00 dan hanya 13 orang memiliki IPK 2,50 hingga 2,99.

Berikut pada Tabel 4.disajikan hasil dari uji validitas yang telah dilakukan pada data yang telah dikumpulkan.

\section{Tabel 4. Rekapitulasi Hasil Uji Validitas Instrumen Penelitian}

\begin{tabular}{lllll}
\hline Variabel & Indikator & $\begin{array}{l}\text { Koefisien } \\
\text { Korelasi }\end{array}$ & Sig.(2-tailed) & Keterangan \\
\hline Pertimbangan & $\mathrm{X}_{1.1}$ & 0,855 & 0,000 & Valid \\
pasar kerja $\left(\mathrm{X}_{1}\right)$ & $\mathrm{X}_{1.2}$ & 0,875 & 0,000 & Valid \\
& $\mathrm{X}_{1.3}$ & 0,861 & 0,000 & Valid \\
& $\mathrm{X}_{2.1}$ & 0,598 & 0,000 & Valid \\
Pelatihan & $\mathrm{X}_{2.2}$ & 0,730 & 0,000 & Valid \\
profesional $\left(\mathrm{X}_{2}\right)$ & $\mathrm{X}_{2.3}$ & 0,758 & 0,000 & Valid \\
& $\mathrm{X}_{2.4}$ & 0,746 & 0,000 & Valid \\
& $\mathrm{X}_{2.5}$ & 0,716 & 0,000 & Valid \\
& $\mathrm{X}_{3.1}$ & 0,811 & 0,000 & Valid \\
& $\mathrm{X}_{3.2}$ & 0,797 & 0,000 & Valid \\
Personalitas $\left(\mathrm{X}_{3}\right)$ & $\mathrm{X}_{3.3}$ & 0,796 & 0,000 & Valid \\
& $\mathrm{X}_{3.4}$ & 0,790 & 0,000 & Valid \\
& $\mathrm{X}_{3.5}$ & 0,858 & 0,000 & Valid \\
& $\mathrm{X}_{3.6}$ & 0,759 & 0,000 & Valid \\
Minat Mahasiswa & $\mathrm{Y}_{2}$ & 0,748 & 0,000 & Valid \\
Akuntansi $\quad$ Pada & $\mathrm{Y}_{3}$ & 0,777 & 0,000 & Valid \\
Pemilihan Karir & $\mathrm{Y}_{4}$ & 0,819 & 0,000 & Valid \\
(Y) & $\mathrm{Y}_{5}$ & 0,796 & 0,000 & Valid \\
& $\mathrm{Y}_{6}$ & 0,821 & 0,000 & Valid \\
\hline
\end{tabular}

Sumber : Data Penelitian, 2019

Agar dapat digunakan sebagai instrument penelitian, syarat yang harus dipenuhi adalah nilai koefisien korelasi yang melebihi 0,30 serta nilai signifikansi yang tidak melebihi 0,05 . Syarat ini berhasil dipenuhi dan instrument yang dipilih layak untuk digunakan dalam penelitian.

Berikut pada Tabel 5. disajikan hasil dari uji reliabilitas yang telah dilakukan pada data yang telah dikumpulkan.

Tabel 5. Rekapitulasi Hasil Uji Reliabilitas Instrumen Penelitian

\begin{tabular}{llll}
\hline No. & Variabel & Cronbach's Alpha & Keterangan \\
\hline 1 & Pertimbangan pasar kerja $\left(\mathrm{X}_{1}\right)$ & 0,851 & Reliabel \\
2 & Pelatihan profesional $\left(\mathrm{X}_{2}\right)$ & 0,778 & Reliabel \\
3 & Personalitas $\left(\mathrm{X}_{3}\right)$ & 0,799 & Reliabel \\
4 & Minat Mahasiswa Akuntansi pada & 0,793 & Reliabel \\
& pemilihan karir $(\mathrm{Y})$ & &
\end{tabular}

Sumber : Data Penelitian, 2019

Syarat yang harus dipenuhi agar variable yang digunakan dapat dikataka andal atau reliable adalah nilai Cronbach's Alpha yang melebihi 0,60. Dari data 
yang disajikan pada Tabel 5.Disimpulkan bahwa semua variable yang digunakan merupakan andal atau reliable karena telah memenuhi syarat yang ditentukan.

Berikut pada Tabel 6.disajikan hasil dari uji statistic deskriptif yang telah dilakukan pada data yang telah dikumpulkan.

Tabel 6. Hasil Statistik Deskriptif Variabel Penelitian

\begin{tabular}{lllllr}
\hline & & & & & Std. \\
& $\mathrm{N}$ & Minimum & Maximum & Mean & Deviation \\
\hline Pertimbangan Pasar & 182 & 6,00 & 15,00 & 11,49 & 2,11 \\
Pelatihan Profesional & 182 & 11,00 & 24,00 & 18,87 & 2,92 \\
Personalitas & 182 & 14,00 & 30,00 & 23,61 & 4,16 \\
Minat Mahasiswa & 182 & 14,00 & 30,00 & 23,31 & 3,78 \\
Valid N (listwise) & 182 & & & & \\
\hline
\end{tabular}

Sumber : Data Penelitian, 2019

Rata-rata yang dihasilkan untuk masing-masing variable yang digunakan yaitu 11,49 untuk pertimbangan pasar kerja, 18,87 untuk pelatihan professional, 223,61 untuk personalitas, serta 23,31 untuk minat mahasiswa nilai rata-rata ini berarti tingginya pertimbangan pasar kerja, pelatihan professional, dan personalitas yang dimiliki oleh responden selain itu minat mahasiswa juga tergolong tinggi. Kriteria tinggi untuk rata-rata tiap variable adalah jika nilai rata-ratanya berada pada range 3,40-4,20 dan sudah jelas bahwa nilai rata-rata untuk semua variable termasuk kategori tinggi. Selain nilai rata-rata pada statistic deskriptif juga dijabarkan nilai minimum maupun nilai maksimum yang didapatkan dari masing-masing variabel.

Berikut pada Tabel 7. disajikan hasil dari uji normalitas yang telah dilakukan pada data yang telah dikumpulkan

Tabel 7. Hasil Uji Normalitas

\begin{tabular}{lll}
\hline & & $\begin{array}{l}\text { Unstandardized } \\
\text { Residual }\end{array}$ \\
\hline $\mathrm{N}$ & & 182 \\
Normal Parametersa,b & Mean & 0,0000000 \\
& Std, Deviation & 1,68326179 \\
Most Extreme Differences & Absolute & 0,038 \\
& Positive & 0,038 \\
Kolmogorov-Smirnov Z & Negative & $-0,026$ \\
Asymp. Sig. (2-tailed) & & 0,518 \\
Sumber: Data Penelitian, 2019 & 0,951
\end{tabular}

Sumber : Data Penelitian, 2019

Agar dikategorikan berdistribusi normal, nilai signifikansi yang didapatkan haruslah melebihi 0,05. Jika tidak maka model regresi yang digunakan tidak berdistribusi secara normal.Pada hasil yang disajikan pada Tabel 8. Nilai signifikansi Kolmogorov-Smirnov telah melebihi 0,05 maka model regresi yang digunakan berdistribusi normal.

Berikut pada Tabel 8.disajikan hasil dari uji multikolinearitas yang telah dilakukan pada data yang telah dikumpulkan

Tabel 8. Hasil Uji Multikoleniaritas

\begin{tabular}{llll}
\hline Variabel & Tolerance & VIF & Keterangan \\
\hline Pertimbangan pasar kerja $\left(X_{1}\right)$ & 0,404 & 2,477 & Bebas multikol \\
Pelatihan profesional $\left(\mathrm{X}_{2}\right)$ & 0,435 & 2,301 & Bebas multikol \\
\hline
\end{tabular}


Personalitas $\left(\mathrm{X}_{3}\right)$

0,409

2,446

Bebas multikol

Sumber : Data Penelitian, 2019

Nilai tolerance yang melebihi 10 persen dan nilai VIF yang kurang dari 10 merupakan syarat agar pada uji multikolinearitas ini model persamaan regresi yang digunakan dinyatakan terbebas dari masalah multikolinearitas.Berdasarkan hasil yang disajikan pada Tabel 8.Dapat dilihat bahwa seluruh variabel yang digunakan telah memenuhi syarat untuk dikategorikan sebagai terbebas $\mathrm{dr}$ masalah multikolinearitas.

Berikut pada Tabel 9. disajikan hasil dari uji heteroskedastisitas yang telah dilakukan pada data yang telah dikumpulkan

Tabel 9. Hasil Uji Heteroskedastisitas

\begin{tabular}{lll}
\hline Variabel & Signifikansi & Keterangan \\
\hline Pertimbangan pasar kerja $\left(\mathrm{X}_{1}\right)$ & 0,727 & Bebas heteroskedastisitas \\
Pelatihan profesional $\left(\mathrm{X}_{2}\right)$ & 0,412 & Bebas heteroskedastisitas \\
Personalitas $\left(\mathrm{X}_{3}\right)$ & 0,983 & Bebas heteroskedastisitas \\
\hline
\end{tabular}

Sumber : Data Penelitian, 2019

Model persamaan yang digunakan dikatan baik jika terbebas dari masalah heteorkedastisitas. Syarat agar terbebas dari masalah heteroskedastisitas adalah nilai signifikansi yang melebihi 0,05 . Pada Tabel 10. dapat dilihat hasil yang didapat adalah seluruh variabel memiliki nilai signifikansi yang melebihi 0,05 oleh karena itu syarat agar model persamaan tidak memiliki masalah heteroskedastisitas terpehuni.

Berikut pada Tabel 10.disajikan hasil dari analisis regresi linear berganda yang telah dilakukan pada data yang telah dikumpulkan

Tabel 10. Hasil Analisis Regresi Linier Berganda

\begin{tabular}{lllll}
\hline Variabel & $\begin{array}{l}\text { Unstandardized } \\
\text { Coefficients }\end{array}$ & Std. Error & T hitung & Sig. \\
\hline (Constant) & 0,952 & 0,854 & 1,115 & 0,266 \\
Pertimbangan Pasar & 0,517 & 0,094 & 5,490 & 0,000 \\
Pelatihan Profesional & 0,521 & 0,066 & 7,952 & 0,000 \\
Personalitas & 0,279 & 0,047 & 5,874 & 0,000 \\
\hline
\end{tabular}

Sumber : Data Penelitian, 2019

Persamaan regresi berdasarkan hasil yang ditunjukkan pada Tabel 11. yaitu:

$$
\mathrm{Y}=0,952+0,517 \mathrm{X}_{1}+0,521 \mathrm{X}_{2}+0,279 \mathrm{X}_{3}+\mathrm{e}
$$

Dari persamaan yang telah terbentung dapat dijelaskan bahwa nilai konstanta (a) yang dihasilkan yaitu 0,952 memiliki arti niat mahasiswa akuntansi pada pemilihan karir memiliki nilai 0,952 dengan variabel bebas lainnya yaitu pertimbangan pasar kerja, pelatihan professional serta personalitas konstan atau 0 . Selanjutnya untuk variabel pertimbangan pasar kerja $\left(\beta_{1}\right)$ didapatkan niai koefisien regresinya yaitu bernilai positif 0,517 yang berarti ketika pertimbangan pasar kerja mengalami kenaikan akan berdampak pada meningkatnya minat mahasiswa akuntansi dalam memilih karir diasumsikan variabel lainnya konstan. Untuk variabel pelatihan professional $\left(\beta_{2}\right)$ didapatkan niai koefisien regresinya yaitu bernilai positif 0,521 yang berarti ketika pelatihan profesional mengalami kenaikan akan berdampak pada meningkatnya minat mahasiswa akuntansi dalam memilih karir diasumsikan variabel lainnya konstan. Terakhir untuk variabel personalitas $\left(\beta_{3}\right)$ didapatkan niai koefisien regresinya yaitu 
bernilai positif 0,279 yang berarti ketika personalitas mengalami kenaikan akan berdampak pada meningkatnya minat mahasiswa akuntansi dalam memilih karir diasumsikan variabel lainnya konstan

Berikut pada Tabel 11. disajikan hasil dari uji F yang telah dilakukan pada data yang telah dikumpulkan

Tabel 11. Hasil Uji F

\begin{tabular}{lllllll}
\hline Model & & $\begin{array}{l}\text { Sum } \\
\text { of Squares }\end{array}$ & df & Mean Square & F & Sig. \\
\hline 1 & Regression & 2071.539 & 3 & 690.513 & 239.668 & $0.000^{\mathrm{a}}$ \\
& Residual & 512.840 & 178 & 2.881 & & \\
& Total & 2584.379 & 181 & & & \\
\hline
\end{tabular}

Sumber: Data Penelitian, 2019

Pada Tabel 11. disajikan hasil dari uji $\mathrm{F}$ dimana didapatkan hasil $\mathrm{F}$ hitung 239,668 serta nilai $\mathrm{P}$ value yang kurang dari 0,05 maka disimpulkan seluruh variabel bebas yang digunakan memiliki pengaruh yang signifikan pada variabel terikat yang digunakan pada penelitian yaitu minat mahasiswa akuntansi pada pemilihan karir.

Berikut pada Tabel 12. disajikan hasil dari uji koefisien determinasi yang telah dilakukan pada data yang telah dikumpulkan

\section{Tabel 12. Hasil Uji Koefisien Determinasi}

\begin{tabular}{|c|c|c|c|c|}
\hline Model & $\mathrm{R}$ & R Square & Adjusted R Square & $\begin{array}{l}\text { Std. Error of the } \\
\text { Estimate }\end{array}$ \\
\hline 1 & $0,895^{a}$ & 0,802 & 0,798 & 10,697 \\
\hline
\end{tabular}

Sumber : Data Penelitian, 2019

Nilai adjusted $\mathrm{R}^{2}$ yang ditampilkan pada Tabel 12. yaitu 0,798 memiliki ari bahwa variabel bebas yang digunakan pada penelitian yaitu pertimbangan pasar kerja, pelatihan professional serta personalitas dapan menjelaskan variabel terikat yang digunakan pada penelitian yaitu minat mahasiswa akuntansi pada pemilihan karir sebesar 79,8 persen. 20,2 persen sisanya dijelaskan oleh variabel lain diluar model persamaan penelitian ini.

Berdasarkanhasil uji hipotesis didapatkan hasil bahwa ketiga hipotesis yang diajukan diterima. Untuk hipotesis pertama mengenai hubungan pertimbangan pasar kerja terhadap minat mahasiswa akuntansi pada pemilihan karir yaitu berpengaruh positif dilihat dari nilai koefisien regresi 0,517 dan signifikansi yang kurang dari 0,05. Hipotesis kedua yaitu hubungan pelatihan professional terhadap minat mahasiswa akuntansi pada pemilihan karir yaitu hipotesis diterima dengan nilai koefisien regresi 0,521 dan signifikansi yang kurang dari 0,05. Hipotesis ketiga yaitu hubungan personalitas terhadap minat mahasiswa akuntansi pada pemilihan karir yaitu hipotesis diterima dengan nilai koefisien regresi 0,279 dan signifikansi yang kurang dari 0,05. Dapat disimpulkan bahwa dari pengujian hipotesis terdapat hubungan positif antara pertimbangan pasar kerja, pelatihan professional serta personalitas terhadap minat mahasiswa akuntansi pada pemilihan karir.

Hasil dari pengujian pada hipotesis pertama menunjukkan bahwa terdapat hubungan positif antara pertimbangan pasar kerja terhadap minat mahasiswa akuntansi pada pemilihan karir. Mahasiswa akuntansi mempertimbangkan rasa aman dalam karir yang akan dipilihnya. Selain itu 
semakin mudahnya informasi yang didapatkan mengenai suatu lapangan pekerjaan akan meningkatkan minat mahasiswa akuntansi untuk memilih karir. Didukung oleh penelitian sebelumnya yang dilakukan oleh Linanda (2016) dan Suyono (2014) yang menemukan hal yang sama mengenai hubungan pertimbangan pasar kerja terhadap minat mahasiswa dalam memilih karir.

Hasil dari pengujian hipotesis kedua yaitu pelatihan professional berpengaruh positif terhadap minat mahasiswa akuntansi pada pemilihan karir.Mahasiswa akuntansi memiliki pandangan yang positif mengenai pelatihan-pelatihan professional. Hasil dari penelitian ini juga ditemukan oleh peneliti sebelumnya yang meneliti topic yang sama yaitu penelitian yang dilakukan oleh Ardianto (2014) dan Agmila (2015).

Pada pengujian hipotesis ketiga hasil yang didapatkan adalah adanya pengaruh positif antara personalitas terhadap minat mahasiswa akuntansi pada pemilihan karir. Hasil ini didukung oleh penelitian sebelumnya yaitu penelitian yang dilakukan oleh Suyono (2014) dan Ambari (2017).

\section{SIMPULAN}

Berdasarkan hasil uji hipotesis didapatkan hasil bahwa ketiga hipotesis yang diajukan diterima. Dapat disimpulkan bahwa dari pengujian hipotesis terdapat hubungan positif antara pertimbangan pasar kerja, pelatihan professional serta personalitas terhadap minat mahasiswa akuntansi pada pemilihan karir.Peneliti selanjutnya disarankan untuk memperluas sampel yang digunakan agar hasilnya dapat digeneralisasikan misalnya seperti menggunakan responden dari mahasiswa jurusan akuntansi di luar Universitas Udayana. Hal ini juga dapat berguna untuk memberikan informasi kepada mahasiswa di luar Universitas Udayana mengenai pemilihan karir yang yang tepat.Penelitian berikutnya juga dapat menambah variabel-variabel lain yang dapat mempengaruhi minat Mahasiswa Akuntansi pada pemilihan karir seperti variabel gender, lingkungan keluarga ataupun variabel lainnya.

\section{REFERENSI}

Ajzen, I. (1991). The Theory Of Planned Behavior:Organizational Behavior And Human Decision Processes. (50th Ed.). Amhest: University Of Massachusetts Academic Press. Inc.

Allport, G. W. (1961). Pattern And Growth In Personality. New York: Holt: Rinehart \& Winston.

Ardianto, N. (2014). Faktor-Faktor Yang Mempengaruhi Minat Mahasiswa Akuntansi Terhadap Pemilihan Karir Akuntan Atau Non Akuntan.

Arif, W. R., Nazar, M. R., \& Kurnia. (2018). Pengaruh Sanksi Perpajakan, Kualitas Pelayanan, Dan Pengetahuan Wajib Pajak Terhadap Kepatuhan Wajib Pajak (Studi Pada Wajib Pajak Orang Pribadi Non Karyawan Yang Melakukan Usaha Dan Pekerjaan Bebas Di Kpp Pratama Sumedang Tahun 2017). EProceeding Of Management, 5(1), 820.

Efendi, J., Mulig, E. V., \& Smith, L. M. (2007). Information Technology And Systems Research Published In Major Accounting Academic And Professional Journals. Journal Of Emerging Technologies In Accounting, 3(1), 117-128. Https:/ / Doi.Org/10.2308/Jeta.2006.3.1.117 
Gomes, F. C. (2000). Manajemen Sumber Daya Manusia (4th Ed.). Yogyakarta: Andi.

Harahap, Y. A. (2017). Factors Affecting The Interests Of Accounting Students Study Program Selection Career Public Accountants, 1(1), 51-61.

Iswahudin, M. (2015). Pengaruh Penghargaan Finansial Dan Pertimbangan Pasar Kerja Terhadap Pemilihan Profesi Sebagai Akuntan Profesional(Studi Kasus Pada Mahasiswa Akuntansi Universitas Negeri Yogyakarta). Skripsi. Fakultas Ekonomi. Universitas Negeri Yogyakarta.

Rasmini. (2007). Faktor-Faktor Yang Berpengaruh Pada Keputusan Pemilihan Profesi Akuntan Publik Dan Non Akuntan Publik Pada Mahasiswa Akuntansi Di Bali. Jurusan Akuntansi Fakultas Ekonomi, Universitas Udayana, Denpasar. (2007), 12.

Ambari. (2017).Kerja, P. P., Profesional, P., Sosial, N., Kerja, L., Pemilihan, P., Sebagai, K., \& Publik, A. (2017). Fakultas Ekonomi Dan Bisnis Universitas Udayana ( Unud ), Bali , Indonesia Fakultas Ekonomi Dan Bisnis Universitas Udayana ( Unud ), Bali, Indonesia Karir Tersebut . Semua Mahasiswa Tentunya Memiliki Harapan Atau Cita-Cita Kerja Yang Semakin Ketat Dan Pe, 18, 705-734.

Kharis Raharjo, Se.Msi,Ak ; Rita Andini, Se.Mm. (N.D.), 1-19.

Nana. (2018). Faktor-Faktor Yang Mempengaruhi Minat Mahasiswa Pada Pemilihan Karir.Pemilihan, K. D. (2018). No Title.

Stolle, S. D. (1976). Student's View Of The Public And Industrial Accountant. Jurnal Of Accountancy.

Sugiyono. (2017). Metode Penelitian Pendidikan Pendekatan Kuantitatif, Kualitatif, Dan RED. Bandung: Alfabeta.

Suroto. (2016). Determinan Nilai Perusahaan. Jurnal Universitas 17 Agustus 1945 Semarang, 5(1), 38-53.

Suyono. 2014. Analisis Faktor-Faktor Yang Mempengaruhi Pemilihan Karir Sebagai Akuntan Publik (Studi Empiris Pada Mahsiswa Akuntansi UNSiQ). Jurnal PPKM II. Hal 69-83.

Linanda, Yendrawati,Nila. 2016.Relevansi Pemahaman Mahasiswa Akuntansi Terhadap Faktor-Faktor Yang Melatarbelakangi Keputusan Pemilihan Karir Akuntan Publik Dan Non Akuntan Publik.

Agmila. 2015. "Pengaruh Gaya Belajar Terhadap Motivasi dan Hasil Belajar Peserta Didik MIN Jati Pandansari Ngunut Tulungagung". Skripsi. Fakultas Tarbiyah dan Ilmu Keguruan IAIN Tulungagung. (Online) repo.iaintulungagung.ac.id(04 Juli 2017) 